JIIA, VOLUME 6 No. 3, AGUSTUS 2018

\title{
EFISIENSI TEKNIS USAHATANI BAWANG MERAH DI KECAMATAN KETAPANG KABUPATEN LAMPUNG SELATAN
}

\author{
(Technical Efficiency of Onion in Ketapang Sub-District, South Lampung Regency) \\ Hardini Tristya, Ktut Murniati, Muhammad Irfan Affandi
}

Jurusan Agribisnis, Fakultas Pertanian, Universitas Lampung, J1. Prof. Dr. Soemantri Brojonegoro No. 1

Bandar Lampung 35145, Telp. 08576878422, e-mail: hardinitristya@ gmail.com

\begin{abstract}
This study aims to analyze technical efficiency of onion farming and the factors that influence the technical inefficiency of onion farming. This research is conducted purposely in Ketapang Sub-district. The respondents are 49 farmers collected by sensus method. He research data is taken in September to November 2016. The technical efficiency is measured by frontier production function and estimated by Maximum Likelihood Estimation (MLE) method with Frontier 4.1c computer program. The estimation of factor that influences the technical inefficiency is applied by linear regression model simultaneously obtained by using the frontier production function. The results showed that the average of technical efficiency of onion farming in Ketapang Sub-district was 0.93 which meant very efficient. Furthermore, the factors that significantly influenced the technical inefficiency of onion farm in Ketapang Sub-district were the farming experience and counseling frequency.
\end{abstract}

Key words: frontier, onion farming, technical efficiency

\section{PENDAHULUAN}

Bawang merah merupakan salah satu komoditas sayuran unggulan yang sejak lama telah diusahakan oleh petani secara intensif. Pengusahaan budidaya bawang merah telah menyebar di hampir semua provinsi di Indonesia. Berdasarkan data dari BPS dan Direktorat Jenderal Holtikultura tahun 2017, produksi bawang merah di Indonesia tahun 2016 menunjukkan bahwa bawang merah telah diusahakan dihampir semua provinsi di Indonesia kecuali Provinsi Kepulauan Riau.

Provinsi Lampung merupakan salah satu daerah yang mengembangkan komoditas bawang merah. Provinsi Lampung juga terus melakukan upaya untuk meningkatkan produksi bawang merah untuk memenuhi permintaan bawang merah di Lampung yang terus meningkat dan untuk mengurangi impor bawang merah dari luar daerah.

Terdapat enam kabupaten/kota di Provinsi Lampung yang memproduksi bawang merah pada tahun 2016, yaitu Kabupaten Lampung Barat, Tanggamus, Lampung Selatan, Pesawaran, Pringsewu, dan Metro. Lampung Selatan merupakan kabupaten dengan luas panen, produksi dan produktivitas tertinggi.
Produksi bawang merah di Provinsi Lampung pada tahun 2014 (944 ton) mengalami peningkatan sebanyak 328,64\% dibandingkan pada tahun 2013, dikarenakan terjadinya peningkatan produksi bawang merah yang relatif besar terjadi di Kabupaten Lampung Selatan (BPS Provinsi Lampung, 2015). Namun, tingkat produktivitas bawang merah di Kabupaten Lampung Selatan masih tergolong rendah yaitu 13,75 ton/ha, sementara itu menurut Badan Penelitian dan Pengembangan Pertanian, potensi tingkat produktivitas bawang merah di Indonesia dapat mencapai lebih dari 20 ton/ha. Meskipun demikian, Kabupaten Lampung Selatan memiliki potensi untuk menjadi daerah sentra bawang merah di Lampung karena memiliki iklim yang sesuai. Oleh karena itu, pemerintah Kabupaten Lampung Selatan mencanangkan program dengan tujuan untuk mengembangkan potensi wilayah dengan cara memberikan bantuan bibit dan pupuk kepada para petani bawang merah sejak tahun 2013.

Menurut data dari Dinas Pertanian Tanaman Pangan dan Hortikultura Kabupaten Lampung Selatan tahun 2015, terdapat enam kecamatan penghasil bawang merah di Kabupaten Lampung Selatan. Kecamatan Ketapang memiliki luas panen dan produksi tertinggi. Sebesar 456,5 ton $(73,69 \%)$ dari jumlah total produksi bawang merah berasal dari Kecamatan Ketapang. Hal ini menunjukkan bahwa Kecamatan Ketapang dapat 
JIIA, VOLUME 6 No. 3, AGUSTUS 2018

dikatakan berhasil dalam mengembangkan bibit bantuan bawang merah. Potensi komoditas bawang merah di Kecamatan Ketapang tersebut perlu dipertahankan dan terus ditingkatkan, antara lain dengan pemanfaatan sumber daya yang dimiliki agar usahatani menjadi lebih efisien.

Produktivitas bawang merah yang tergolong rendah berkaitan dengan efisiensi produksi. Untuk meningkatkan rendahnya produktivitas bawang merah maka diperlukan peningkatan efisiensi pada usahatani bawang merah. Kombinasi penggunaan faktor - faktor produksi akan mempengaruhi besarnya produksi yang dihasilkan. Penggunaan sarana produksi yang tidak optimal dan tidak efisien menyebabkan usahatani bawang merah yang dilakukan tidak dapat menuai hasil produksi yang maksimal. Jika produksi yang dihasilkan petani rendah maka akan berdampak pada rendahnya pendapatan petani.

Sumaryanto (2001) menyatakan bahwa terdapat faktor internal dan eksternal sehingga petani tidak dapat mencapai efisiensi tertinggi. Faktor internal yang merupakan kemampuan teknis dan manajerial petani dalam usaha tani meliputi luas dan penguasaan lahan, pendidikan, umur, pendapatan, pengalaman, penguasaan teknologi serta kemampuan petani mengolah informasi untuk meningkatkan produksinya. Faktor eksternal meliputi hal-hal di luar kendali petani seperti bencana alam, iklim, harga, penyakit dan hama tumbuhan dan lainnya.

Berdasarkan faktor internal dan eksternal tersebut maka petani harus dapat mengalokasikan faktor produksi yang digunakan sedemikian rupa agar dapat menghasilkan produksi yang optimal, untuk mendapatkan keuntungan yang maksimal. Berdasarkan masalah di atas, maka penelitian ini bertujuan untuk menganalisis efisiensi teknis usahatani bawang merah dan faktor-faktor yang mempengaruhi inefisiensi teknis usahatani bawang merah di Kecamatan Ketapang Kabupaten Lampung Selatan.

\section{METODE PENELITIAN}

Penelitian ini dilakukan dengan menggunakan metode survei di Desa Berundung dan pematang Pasir Kecamatan Ketapang Kabupaten Lampung Selatan. Pemilihan lokasi penelitian ditentukan secara sengaja (purposive) dengan pertimbangan bahwa produksi bawang merah di Kecamatan tersebut terbesar di Kabupaten Lampung Selatan dan jumlah petani bawang merah di kedua desa tersebut terbanyak.
Pengumpulan data dilakukan pada bulan September - November 2016. Metode penentuan responden dilakukan dengan metode sensus, yaitu mengambil seluruh petani di Desa Berundung dan Desa Pematang Pasir dengan jumlah sebanyak 49 orang petani.

Jenis data yang digunakan dalam penelitian ini adalah data primer dan data sekunder. Data primer diperoleh melalui wawancara secara langsung kepada responden menggunakan kuesioner sebagai alat bantu, sedangkan data sekunder diperoleh dari studi literatur, laporan, serta lembaga/instansi yang terkait dalam penelitian ini, seperti Badan Pusat Statistik, Dinas Pertanian Kabupaten Lampung Selatan dan Badan Pelaksanaan Penyuluhan Pertanian Perikanan dan Kehutanan (BP3K) Kecamatan Ketapang.

Data penelitian ini dianalisis secara kuantitatif dengan analisis efisiensi teknis dan faktor-faktor yang mempengaruhi inefisiensi teknis. Model empiris fungsi produksi yang digunakan dalam penelitian adalah stochastic frontier CobbDouglas. Dengan memasukkan sepuluh variabel bebas ke dalam fungsi produksi stochastic frontier Cobb-Douglas maka secara matematis model persamaan penduga fungsi produksi stochastic frontier pada usahatani bawang merah dalam penelitian ini dapat ditulis sebagai berikut.

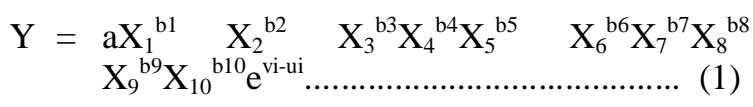

Keterangan:

$$
\begin{aligned}
\mathrm{Y} & =\text { Produksi bawang merah }(\mathrm{kg}) \\
\mathrm{X}_{1} & =\text { Luas lahan }(\mathrm{ha}) \\
\mathrm{X}_{2} & =\text { Jumlah bibit }(\mathrm{kg}) \\
\mathrm{X}_{3} & =\text { Jumlah pupuk kandang }(\mathrm{kg}) \\
\mathrm{X}_{4} & =\text { Jumlah pupuk SP-36 }(\mathrm{kg}) \\
\mathrm{X}_{5} & =\text { Jumlah pupuk KCl }(\mathrm{kg}) \\
\mathrm{X}_{6} & =\text { Jumlah pupuk daun }(\mathrm{lt}) \\
\mathrm{X}_{7} & =\text { Jumlah insektisida (lt) } \\
\mathrm{X}_{8} & =\text { Jumlah tenaga kerja (HKP) } \\
\mathrm{a} & =\text { Konstanta } \\
\mathrm{b}_{\mathrm{i}}= & \text { Koefisien regresi, dimana i }=1,2, \ldots 10 \\
\mathrm{v}_{\mathrm{i}}-\mathrm{u}_{\mathrm{i}}= & \text { Error term (efek inefisiensi di dalam } \\
& \text { model) }
\end{aligned}
$$

Analisis efisiensi teknis dapat diestimasi dengan menggunakan rumus:

$$
\begin{aligned}
& \text { TEI }=\frac{Y_{i}}{Y_{i}^{*}}=\frac{\exp \left(Y_{i}\right)}{\exp \left(Y_{i}+u_{i}\right)}=\frac{\exp \left(X_{i} \beta+v_{i}-u_{i}\right)}{\exp \left(X_{i} \beta+v_{i}+u_{i}\right)} \\
& =\operatorname{Exp}\left(-\mathrm{u}_{\mathrm{i}}\right)
\end{aligned}
$$


Keterangan:

$\mathrm{Yi}=$ Produksi aktual dari pengamatan

$\mathrm{Y}^{*}=$ Dugaan produksi frontier stokastik

Metode inefisiensi teknis yang digunakan dalam penelitian ini mengacu pada model efek inefisiensi teknis yang dikembangkan oleh Coelli et al. (1998). Faktor-faktor yang diperkirakan mempengaruhi tingkat inefisiensi teknis petani bawang merah dalam penelitian ini adalah umur petani $\left(Z_{1}\right)$, pengalaman berusahatani $\left(Z_{2}\right)$, tingkat pendidikan $\left(Z_{3}\right)$, dan frekuensi penyuluhan $\left(Z_{4}\right)$. Maka persamaan model estimasi dampak inefisiensi pada penelitian adalah sebagai berikut :

$\mathrm{u}_{\mathrm{i}}=\delta_{0}+\delta_{1} \mathrm{Z}_{1}+\delta_{2} \mathrm{Z}_{2}+\delta_{3} \mathrm{Z}_{3}+\delta_{4} \mathrm{Z}_{4}$

Seluruh parameter baik dalam fungsi stochastic frontier dan efek inefisiensi secara simultan dapat diperoleh melalui program Frontier 4.1.

Sebagai kaidah pengujian hipotesis:

a) Jika t-hitung $>\mathrm{t}$-tabel, maka tolak $\mathrm{H}_{0}$ yang berarti masing-masing variabel penjelas dalam model efek inefisiensi memiliki pengaruh terhadap tingkat inefisiensi dalam proses produksi.

b) Jika t-hitung < t-tabel, maka terima $\mathrm{H}_{0}$ yang berarti masing-masing variabel penjelas dalam model efek inefisiensi tidak memiliki pengaruh terhadap tingkat inefisiensi dalam proses produksi.

\section{HASIL DAN PEMBAHASAN}

\section{Karakteristik Responden}

Berdasarkan hasil penelitian yang diperoleh, komposisi umur petani responden berkisar antara 29 - 65 tahun dengan rata-rata yaitu 46 tahun. Hal ini menunjukkan bahwa petani bawang merah di daerah penelitian berusia produktif. Menurut Mantra (2004), kelompok umur 15-64 tahun merupakan kelompok usia produktif, dan kelompok umur di atas 65 tahun merupakan kelompok usia tidak lagi produktif.

Tingkat pendidikan petani responden tertinggi berada pada tingkat pendidikan tamat SMA sederajat sebanyak $38,78 \%$, yang berarti bahwa petani di lokasi penelitian sudah memiliki pendidikan yang cukup baik. Sebanyak 44,90\% petani responden tidak memiliki pekerjaan sampingan. Sebesar 42,86\% memiliki pekerjaan di bidang off farm sebagai buruh tani dan petambak, dan sisanya memiliki pekerjaan di bidang non farm. Pekerjaan off farm yang dilakukan petani responden yaitu sebagai petambak dan buruh tani, sedangkan non farm yaitu warung dan pedagang.

Luas lahan usahatani bawang merah di daerah penelitian berkisar antara $0,125-0,750$ ha, dengan rata - rata luas lahan sebesar 0,27 ha. Luas lahan yang digunakan petani didominasi pada luasan $0,25-0,50$ ha $(51,02 \%)$. Usahatani bawang merah di daerah penelitian masih dalam skala rumah tangga dan bersifat tradisional dengan teknologi yang masih sederhana. Dapat disimpulkan bahwa luas lahan berada pada skala kecil (gurem).

\section{Penggunaan Sarana Produksi}

Salah satu upaya untuk meningkatkan produksi bawang merah adalah dengan penggunaan faktorfaktor produksi seperti menggunakan bibit yang bermutu baik dan menggunakan pupuk yang merupakan sumber makanan bagi tanaman. Varietas bibit bawang merah yang ditanam di lokasi penelitian adalah varietas bima brebes. Petani responden rata-rata menggunakan empat jenis pupuk sebagai upaya meningkatkan produksi, yaitu pupuk kandang, pupuk SP-36, Pupuk KCl, dan pupuk daun.

Berdasarkan rata-rata penggunaan benih dan pupuk oleh petani responden di Kabupaten Lampung Timur yang disajikan pada Tabel 1, diketahui bahwa rata-rata penggunaan bibit dan pupuk per hektar pada usahatani bawang merah belum sesuai dengan anjuran yang telah ditetapkan oleh Badan Penelitian Tanaman Sayuran (2005).

Penggunaan bibit dan pupuk yang belum sesuai akan berdampak pada tanaman sehingga produksi yang dihasilkan tidak optimal. Penggunaan faktorfaktor produksi oleh petani responden harus disesuaikan dengan dosis yang telah direkomendasikan agar memperoleh hasil yang optimal. Jumlah produksi usahatani bawang merah di Kecamatan Ketapang Kabupaten Lampung Selatan per 0,27 ha sebesar $2169,39 \mathrm{~kg}$ atau $8034,77 \mathrm{~kg}$ per ha.

Tabel 1. Rata-rata penggunaan bibit dan pupuk oleh petani responden

\begin{tabular}{lrr}
\hline Jenis Bibit dan Pupuk & $\begin{array}{c}\text { Penggunaan } \\
\text { per ha }\end{array}$ & $\begin{array}{c}\text { Anjuran } \\
\text { per ha }\end{array}$ \\
\hline Bibit (kg) & 989,42 & 1200 \\
Pupuk Kandang (kg) & 6477,70 & 10000 \\
Pupuk SP-36 (kg) & 229,40 & 250 \\
Pupuk KCl (kg) & 118,44 & 200 \\
Pupuk Daun (lt) & 5,40 & - \\
\hline
\end{tabular}


JIIA, VOLUME 6 No. 3, AGUSTUS 2018

\section{Analisis Efisiensi Teknis}

Pada Tabel 2 dapat dilihat bahwa nilai loglikelihood dengan metode MLE $(69,60)$ adalah lebih besar dari nilai log-likelihood dengan metode OLS $(65,60)$ yang berarti fungsi produksi dengan metode MLE ini adalah baik. Nilai sigma-squared $(\sigma)$ adalah sebesar 0,0076 , nilai $(\sigma)$ yang lebih besar dari nol menunjukkan bahwa terdapat pengaruh dari technical inefficiency dalam model. Nilai gamma $(\gamma)$ sebesar 0,819 mengindikasikan bahwa 81,9 persen dari error term yang berada dalam fungsi produksi disebabkan oleh keberadaan inefisiensi teknis, sedangkan 18,1 persen disebabkan oleh variabel kesalahan acak seperti cuaca, hama, dan lainnya yang tidak dapat dikendalikan. Ini berarti model fungsi produksi stochastic frontier yang diperoleh dapat menunjukkan adanya keberadaan inefisiensi teknis pada model.

Adapun model yang terbentuk diperlihatkan pada persamaan sebagai berikut.

$\mathrm{Ln} Y=4,795+0,323 \ln \mathrm{X}_{1}+0,301 \ln \mathrm{X}_{2}+0,155$ $\ln X_{3}+0,069 \ln X_{4}+0,041 \ln X_{5}+0,080 X_{6}+$ $0,005 X_{7}+0,019 X_{8}+v_{i}-u_{i}$

Data pada Tabel 2 memperlihatkan bahwa variabel luas lahan, jumlah bibit, pupuk kandang, pupuk SP-36 dan pupuk daun berkorelasi positif dan berpengaruh nyata terhadap produksi bawang merah, sedangkan variabel insektisida dan tenaga kerja meskipun bernilai positif tetapi tidak berpengaruh nyata. Berikut adalah interpretasi dari model fungsi produksi stochastic frontier yang terbentuk.

Penggunaan lahan berpengaruh positif dan nyata pada taraf kepercayaan 95 persen terhadap produksi bawang merah. Nilai elastisitas lahan terhadap produksi bawang merah sebesar 0,323 menunjukkan bahwa dengan peningkatan luas lahan sebesar satu persen maka akan meningkatkan produksi bawang merah sebesar 0,323 persen, cateris paribus. Hal ini menunjukkan bahwa penggunaan lahan oleh petani masih sempit dan perlu ditingkatkan. Keadaan ini sesuai dengan kondisi aktual yaitu rata-rata luas lahan yang digunakan untuk usahatani bawang merah adalah 0,27 Ha. Hal ini sejalan dengan penelitian Waryanto (2015) tentang analisis keberlanjutan usaha tani bawang merah di Kabupaten Nganjuk Jawa Timur menemukan bahwa variabel luas lahan berpengaruh nyata secara statistik terhadap produksi bawang merah.
Tabel 2. Hasil pendugaan Fungsi Produksi Stochastic Frontier bawang merah dengan menggunakan Metode MLE di Kecamatan Ketapang

\begin{tabular}{|c|c|c|c|}
\hline Variabel & $\begin{array}{c}\text { Koefisien } \\
\text { Regresi }\end{array}$ & $\begin{array}{l}\text { Std } \\
\text { error }\end{array}$ & t-ratio \\
\hline Intercept & $4,795 * * *$ & 1,3092 & 3,6625 \\
\hline Luas lahan (X1) & $0,323 * *$ & 0,1828 & 1,7671 \\
\hline Bibit (X2) & $0,301 * *$ & 0,1597 & 1,8850 \\
\hline Pupuk Kandang (X3) & $0,155^{*}$ & 0,1008 & 1,5418 \\
\hline Pupuk SP-36 (X4) & $0,069^{+}$ & 0,0573 & 1,2088 \\
\hline Pupuk KCl (X5) & 0,041 & 0,0647 & 0,6380 \\
\hline Pupuk Daun (X6) & $0,080 * *$ & 0,0450 & 1,7886 \\
\hline Insektisida (X7) & 0,005 & 0,0057 & 0,9749 \\
\hline Tenaga Kerja (X8) & 0,019 & 0,0864 & 0,2212 \\
\hline Sigma-squared $(\sigma)$ & & 0,0076 & \\
\hline Gamma $(\gamma)$ & & 0,8199 & \\
\hline Log-likelihood OLS & & 65,49 & \\
\hline Log-likelihood MLE & & 69,60 & \\
\hline
\end{tabular}

Keterangan :

$* * *$ = nyata pada tingkat kepercayaan $99 \%(40,0,01=2,423)$

$* *$ = nyata pada tingkat kepercayaan $95 \%(40,0,05=1,694)$

* = nyata pada tingkat kepercayaan $90 \%(40,0,10=1,303)$

$+\quad=$ nyata pada tingkat kepercayaan $85 \%(40,0,15=1,050)$

Jika t-ratio $>$ t-tabel, maka berpengaruh nyata

Jika t-ratio < t-tabel, maka tidak berpengaruh nyata

Penggunaan bibit berpengaruh positif dan nyata pada taraf kepercayaan 95 persen terhadap produksi. Nilai koefisien bibit terhadap produksi bawang merah sebesar 0,301 menunjukkan bahwa dengan penambahan jumlah bibit sebesar satu persen dengan input lainnya tetap akan meningkatkan produksi bawang merah sebesar 0,301 persen. Peningkatan produksi bawang merah dengan penambahan jumlah bibit memiliki proporsi yang cukup besar. Hal ini diduga karena bibit memegang peranan penting dalam mengoptimalkan produksi, semakin bagus kualitas bibit yang digunakan maka produksi yang dihasilkan akan semakin baik. Ini menunjukkan bahwa petani dapat menambahkan jumlah bibit yang digunakan untuk meningkatkan hasil produksi.

Variabel pupuk kandang memiliki nilai koefisien sebesar 0,155 dan berpengaruh nyata terhadap produksi dengan tingkat kepercayaan $90 \%$. Hal ini berarti bahwa penambahan pupuk kandang sebesar satu persen akan meningkatkan produksi sebesar $0,155 \%$, cateris paribus. Hal ini disebabkan karena pupuk kandang memiliki kandungan yang berfungsi untuk menambah unsur hara yang diperlukan oleh tanaman, sehingga penggunaan pupuk kandang dapat meningkatkan produksi dan dapat memperbaiki struktur tanah serta dapat meningkatkan daya tahan air.

Penggunaan pupuk SP-36 berpengaruh nyata terhadap produksi bawang merah pada taraf kepercayaan $80 \%$. Nilai koefisien pupuk SP-36 
sebesar 0,069 berarti bahwa dengan adanya peningkatan penggunaan pupuk SP-36 sebesar satu persen dengan input lainnya tetap, maka akan meingkatkan produksi bawang merah sebesar 0,069 persen. Rata - rata penggunaan pupuk SP36 di lokasi penelitian yaitu $229,4 \mathrm{~kg} / \mathrm{Ha}$. Berdasarkan literatur, anjuran penggunaan pupuk SP-36 untuk tanaman bawang merah adalah 250 $\mathrm{kg} / \mathrm{Ha}$.

Variabel pupuk $\mathrm{KCl}$ bernilai positif namun tidak berpengaruh nyata terhadap produksi bawang merah. Hal ini diduga karena jumlah penggunaan pupuk $\mathrm{KCl}$ oleh petani tidak bervariasi. Harga pupuk $\mathrm{KCl}$ yang lebih mahal jika dibandingkan dengan pupuk lainnya menyebabkan petani menggunakannya dalam jumlah yang relatif sedikit.

Faktor produksi pupuk daun berpengaruh nyata terhadap produksi bawang merah pada taraf kepercayaan 95\%. Nilai koefisien sebesar 0,080 persen menunjukkan bahwa penambahan pupuk daun sebesar satu persen dan input lain tetap akan meningkatkan produksi sebesar 0,080 persen. Pupuk daun berfungsi sebagai pelengkap unsur hara terutama unsur hara mikro, karena pada pupuk akar mayoritas hanya berisi unsur hara makro. Oleh karena itu, pupuk daun sangat dibutuhkan untuk menunjang pertumbuhan tanaman.

Variabel insektisida bernilai positif namun tidak berpengaruh nyata terhadap terhadap produksi bawang merah. Berdasarkan hasil penelitian, petani responden mengendalikan hama dengan cara memotong daun yang terserang hama. Petani akan menggunkan insektisida jika serangan hama meluas, intensitas penyemprotan insektisida dan dosis penggunaan insektisida akan meningkat jika serangan hama semakin membahayakan. Petani menggunakan dosis berdasarkan perkiraan. Pengendalian hama yang tidak diterapkan secara terpadu ini diduga menyebabkan tidak berpengaruhnya penggunaan insektisida terhadap peningkatan produksi bawang merah.

Penggunaan tenaga kerja bernilai positif dan tidak berpengaruh nyata terhadap produksi bawang merah. Hal ini diduga karena penggunaan jumlah tenaga kerja oleh petani kurang bervariasi, sehingga menyebabkan penggunaan tenaga kerja tidak berpengaruh secara signifikan terhadap produksi bawang merah. Hal ini sejalan dengan penelitian Chonani (2014) pada usahatani cabai merah yang menemukan bahwa variabel tenaga kerja tidak berpengaruh nyata secara statistik terhadap produksi bawang merah.

\section{Sebaran Efisiensi teknis}

Efisiensi teknis dianalisis dengan menggunakan model fungsi produksi stochastic frontier. Sebaran efisiensi teknis dari usahatani bawang merah dapat dilihat pada Tabel 3.

Petani dikategorikan efisien jika memiliki nilai indeks lebih dari 0,7 (Sumaryanto 2001). Tabel 3 menunjukkan bahwa nilai rata - rata efisiensi teknis fungsi stochastic frontier yaitu 0,9385 dengan nilai tingkat efisiensi terendah 0,7941 dan tingkat efisiensi tertinggi adalah 0,9870. Berdasarkan nilai rata - rata efisiensi teknis hasil analisis berada pada kategori sangat efisien karena nilainya lebih besar dari 0,7 . Hal ini berarti bahwa petani responden memiliki peluang meningkatkan efisiensi hingga 6,15 persen dengan adopsi teknologi dan teknik pengelolaan yang lebih baik.

Menurut Tajerin (2007), tingkat efisiensi yang tinggi dapat mencerminkan dua hal. Di satu sisi, tingkat efisiensi teknis yang tinggi mencerminkan prestasi petani dalam manajerial usahatani sudah cukup baik dan berada pada level memuaskan. Di sisi lain, tingkat efisiensi teknis yang tinggi juga merefleksikan bahwa peluang yang kecil untuk meningkatkan produksi, karena senjang antara tingkat produksi yang telah dicapai dengan tingkat produksi maksimum yang dapat dicapai dengan pengelolaan terbaik (the best practice) cukup sempit.

\section{Analisis Inefisienai Teknis}

Variabel yang digunakan dalam model efek inefisiensi teknis adalah umur, pendidikan, pengalaman, dan frekuensi penyuluhan. Hasil dari pendugaan efek inefisiensi teknis fungsi produksi stochastic frontier dapat dilihat pada Tabel 4.

Tabel 3. Sebaran petani responden berdasarkan tingkat efisiensi teknis usahatani bawang merah di Kecamatan Ketapang

\begin{tabular}{llrr}
\hline $\begin{array}{c}\text { Efisiensi } \\
\text { Teknis }\end{array}$ & Kategori & $\begin{array}{r}\text { Jumlah } \\
\text { (Orang) }\end{array}$ & $\begin{array}{r}\text { Persentase } \\
(\%)\end{array}$ \\
\hline$<0,7$ & Belum efisien & 1 & 2,04 \\
$0,7-0,9$ & Cukup efisien & 7 & 14,29 \\
$>0,9$ & Sangat Efisien & 41 & 83,67 \\
\hline Total & & 49 & 100 \\
\hline Rata - rata & & \multicolumn{2}{c}{0,9385} \\
Minimum & \multicolumn{2}{c}{0,7941} \\
Maksimum & & \multicolumn{2}{c}{0,9870} \\
\hline
\end{tabular}


JIIA, VOLUME 6 No. 3, AGUSTUS 2018

Tabel 4. Hasil pendugaan efek inefisiensi teknis fungsi produksi stochastic frontier usahatani bawang merah di Kecamatan Ketapang

\begin{tabular}{|c|c|c|c|}
\hline Variabel & $\begin{array}{c}\text { Koefisien } \\
\text { Regresi }\end{array}$ & Std error & t-ratio \\
\hline Intercept & 0,3373 & 0,7648 & 0,4411 \\
\hline Umur (Z1) & 0,0237 & 0,1661 & 0,1428 \\
\hline Pendidikan (Z2) & $-0,1042$ & 0,1547 & $-0,6739$ \\
\hline Pengalaman (Z3) & $-0,1498^{+}$ & 0,1312 & $-1,1141$ \\
\hline Frekuensi & $-0,0103^{\circ}$ & 0,0988 & $-1,0429$ \\
\hline \multicolumn{4}{|l|}{ Penyuluhan (Z4) } \\
\hline Keterangan: & $\begin{array}{l}\text { cayaan } 85 \%(4 \\
\text { rcayaan } 80 \%\end{array}$ & $\begin{array}{c}0,15=1,050) \\
0,20=0,851)\end{array}$ & \\
\hline $\begin{array}{l}\text { Jika t-ratio > t-tabel, } n \\
\text { Jika t-ratio }<\text { t-tabel, } n\end{array}$ & $\begin{array}{l}\text { erpengaruh nya } \\
\text { dak berpengaru }\end{array}$ & & \\
\hline
\end{tabular}

Variabel umur bernilai positif dan tidak berpengaruh nyata terhadap inefisiensi teknis. Penambahan umur petani akan mempengaruhi kondisi fisik sehingga kemampuan bekerja, daya juang dalam berusaha, keinginan untuk menanggung risiko, dan keinginan untuk menerapkan inovasi-inovasi baru akan semakin menurun yang pada akhirnya akan berdampak terhadap peningkatan efisiensi. Akan tetapi, variabel umur tidak berpengaruh nyata diduga karena berdasarkan pengamatan, ada beberapa petani dapat mencapai efisiensi teknis hingga 0,98 persen meskipun berumur lebih tua.

Variabel pendidikan merupakan jumlah tahun yang ditempuh petani dalam menjalankan masa pendidikan formalnya. Variabel pendidikan bernilai negatif tetapi tidak berpengaruh nyata terhadap inefisiensi teknis. Variabel pendidikan yang berkorelasi negatif menjelaskan bahwa semakin lama petani menempuh pendidikan formal maka akan menurunkan tingkat inefisiensi. Akan tetapi, lamanya waktu pendidikan formal yang ditempuh tidak berpengaruh nyata terhadap inefisiensi. Hal ini diduga karna mayoritas petani adalah lulusan SD $(32,65 \%)$ dan SMP $(28,57 \%)$, yang termasuk dalam tingkatan pendidikan yang rendah. Dengan demikian dapat diambil kesimpulan bahwa dengan tingkat pendidikan tersebut petani mampu menjalankan usahatani bawang merah dengan baik.

Pengalaman usahatani dimasukkan dalam model efek inefisiensi teknis dengan dugaan dapat menurunkan tingkat inefisiensi petani bawang merah di daerah penelitian. Hasil yang diperoleh menunjukkan bahwa koefisien variabel pengalaman berusahatani bawang merah terhadap berusahatani bawang merah terhadap tingkat efisiensi teknis bernilai $(-0,1498)$ dan signifikan pada taraf kepercayaan $80 \%$. Hal ini menunjukkan bahwa semakin lamanya pengalaman berusahatani yang dimiliki maka petani maka akan semakin menurunkan tingkat inefisiensi petani bawang merah. Tingkat efisiensi teknis tertinggi berada pada kisaran pengalaman berusahatani $16-$ 20 tahun dengan rata - rata efisiensi teknis sebesar 0,9772 . Hal ini sejalan dengan penelitian Murniati (2014) pada usahatani padi organik yang menyatakan semakin lamanya pengalaman berusahatani maka petani akan semakin efisien dalam mengelola usahataninya.

Frekuensi penyuluhan diukur berdasarkan berapa kali banyaknya petani mengikuti penyuluhan tentang bawang merah dalam rentang waktu setahun terakhir. Hasil yang diperoleh menunjukkan bahwa koefisien variabel pengalaman berusahatani bawang merah terhadap tingkat efisiensi teknis bernilai $(-0,0103)$ dan signifikan pada taraf kepercayaan $80 \%$. Hal ini menunjukkan bahwa dengan adanya penyuluhan akan meningkatkan efisiensi teknis petani bawang merah. Petani yang lebih sering mengikuti penyuluhan (lebih dari satu kali) memiliki tingkat efisisiensi teknis tertinggi yaitu sebesar 0,9701, sedangkan petani yang tidak pernah mengikuti penyuluhan dengan persentase $32,65 \%$ memiliki tingkat efisiensi terendah. Hal ini sejalan dengan penelitian Estariza (2013) pada usahatani tembakau yang menyatakan bahwa keberadaan penyuluh dan intensitas kegiatan penyuluhan sangat dibutuhkan untuk meningkatkan efisiensi.

\section{KESIMPULAN}

Berdasarkan hasil dan pembahasan penelitian, maka dapat disimpulkan bahwa tingkat efisiensi teknis rata-rata usahatani bawang merah di Kecamatan Ketapang Kabupaten Lampung Selatan adalah 0,93 . Hal ini menunjukkan bahwa usahatani bawang merah di Kecamatan Ketapang sangat efisien secara teknis. Faktor-faktor yang mempengaruhi inefisiensi teknis usahatani bawang merah di Kecamatan Ketapang Kabupaten Lampung Selatan adalah pengalaman berusahatani dan frekuensi peyuluhan.

\section{DAFTAR PUSTAKA}

Badan Pusat Statistik. 2015. Lampung Dalam Angka (LDA). Badan Pusat Statistik Provinsi Lampung. Bandar Lampung.

2015. Lampung Selatan Dalam Angka (LSDA). Badan Pusat Statistik Kabupaten Lampung Selatan. Kalianda.

Chonani SH, Prasmatiwi FE, dan Santoso H. 2014. Efisiensi produksi dan pendapatan 
JIIA, VOLUME 6 No. 3, AGUSTUS 2018

usahatani bawang merah di Kecamatan Metro Kibang Kabupaten Lampung Timur: Pendekatan Fungsi Produksi Frontier. JIIA Vol 2 (2): 95-102. http://jurnal.fp. unila.ac.id/ index.php/ JIA/article/view/730/672. [14 Juli 2017].

Coelli TJ, Rao DSP, O'Donnel CJ, Battese GE. 1998. An Introduction to Efficiency and Productivity Analysis. Springer. New York. https://espace.library.uq.edu.au/view/UQ:40 876 [19 Januari 2017].

Estariza Z, Prasmatiwi FE, dan Santoso H. 2013. Efisiensi produksi dan pendapatan usahatani tembakau di Kabupaten Lampung Timur. JIIA Vol 1 (3): 264-270. http://jurnal.fp.unila.ac .id/index.php/JIA/article/view/582. [14 Juli 2017].

Mantra IB. 2004. Demografi Umum. Pustaka Pelajar. Yogyakarta.

Murniati K, Mulyo JH, Irham, dan Hartono S. 2014. Efisiensi teknis usaha tani padi organik lahan sawah tadah hujan di Kabupaten Tanggamus Provinsi Lampung. Jurnal
Penelitian Pertanian Terapan : Vol 14 (1): 31-38.

Sumarni N dan Hidayat A. 2005. Budidaya Bawang Merah. Badan Penelitian Tanaman Sayuran. Lembang. http://balitsa.litbang.per tanian.go.id [7 Februari 2017].

Sumaryanto. 2001. Determinan efisiensi teknis usahatani padi di lahan sawah irigasi. Jurnal Agro Ekonomi : Vol 21 (2): 72-96. http:// ejurnal.litbang.pertanian.go.id/index.php/jae/a rticle/view/4813. [9 April 2017].

Tajerin. 2007. Efisiensi teknis usaha budidaya pembesaran lele di kolam (studi kasus di Kabupaten Tulung Agung, Propinsi) Jawa Timur). Jurnal Ekonomi Pembangunan : Vol 12 (1): 37-48. http://journal.uii.ac.id/index. php/JEP/ article/view/517. [9 April 2017].

Waryanto B. 2015. Analisis Keberlanjutan Usaha Tani Bawang Merah di Kabupaten Nganjuk Jawa Timur. Disertasi. Institut Pertanian Bogor. Bogor. http://repository.ipb.ac.id/ handle/123456789/74101. [17 November 2016]. 